\title{
Radioactive Air Emissions Notice of Construction Sodium Storage Facility
}

\author{
Date Published \\ January 1995
}

\section{DISCLAIMER}

This report was prepared as an account of work sponsored by an agency of the United States Government. Neither the United States Government nor any agency thereof, nor any of their employees, makes any warranty, express or implied, or assumes any legal liability or responsibility for the accuracy, completeness, or usefulness of any information, apparatus, product, or process disclosed, or represents that its use would not infringe privately owned rights. Reference herein to any specific commercial product, process, or service by trade name, trademark, manufacturer, or otherwise does not necessarily constitute or imply its endorsement, recommendation, or favoring by the United States Government or any agency thereof. The views and opinions of authors expressed herein do not necessarily state or reflect those of the United States Government or any agency thereof.

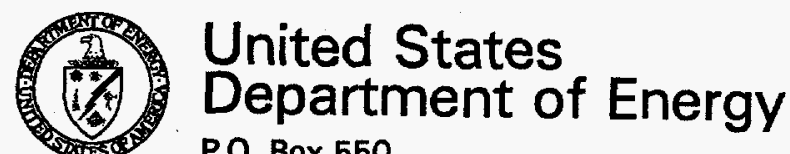

P.O. Box 550

Richland, Washington 99352

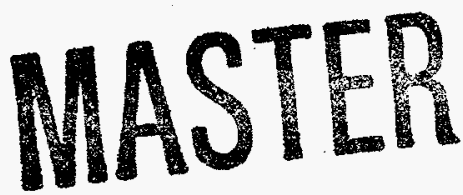

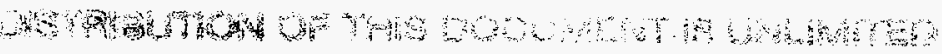

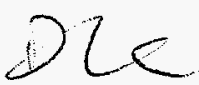




\section{DISCLAIMER}

Portions of this document may be illegible in electronic image products. Images are produced from the best available original document. 


\section{TABLE OF CONTENTS}

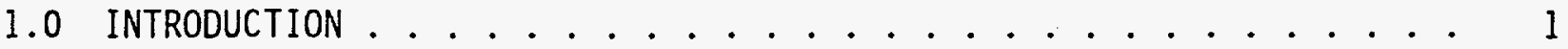

2.0 FACILITY LOCATION (Requirement 1$) \ldots \ldots . \ldots . \ldots 1$

3.0 RESPONSIBLE MANAGER (Requi rement 2) . . . . . . . . . . 4

4.0 TYPE OF PROPOSED ACTION (Requirement 3) . . . . . . . . . 4

5.0 STATE ENVIRONMENTAL POLICY ACT (Requirement 4) . . . . . . . . 4

6.0 PROCESS DESCRIPTION (Requirements 5 and 7 ) . . . . . . . 4

7.0 ANNUAL POSSESSION QUANTITY AND PHYSICAL FORM
(Requirements $8,10,11$, and 12 ) . . . . . . . . . . . 7

8.0 CONTROL SYSTEM (Requirement 6) . . . ........... 8

8.1 FACILITY OVERVIEW . . . . . . . . . . . . . . . 8

8.2 BUILDING VENTILATION ................. 10

8.3 STORAGE TANK COVER GAS SYSTEM ............... 10

9.0 MONITORING SYSTEM (Requirement 9 ) . . . . . . . . . . . 10

10.0 RELEASE RATES (Requirement 13 ) . . . . . . . . . . . 10

10.1 UNABATED EMISSIONS DURING SODIUM TRANSFER OPERATIONS $\ldots \ldots$ l

10.1.1 Tritium Release ............... 11

10.1.2 Aerosol Release .............. 12

10.2 UNABATED EMISSIONS DURING SODIUM STORAGE ......... 13

10.3 SUMMARY OF UNABATED EMISSIONS .............. 13

10.4 ABATED EMISSIONS ...................... 14

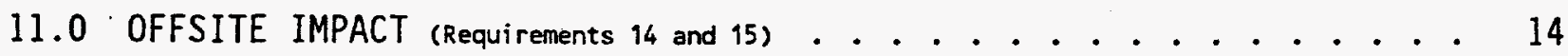

12.0 FACILITY LIFETIME (Requirement 17) . . . . . . . . . . 15

13.0 TECHNOLOGY STANDARDS (Requirement 18) ............. 16

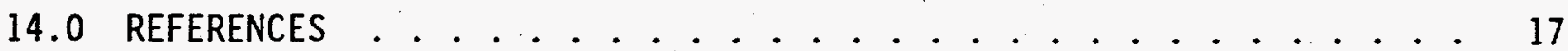
APPENDIX A

DISCUSSION OF BEST AVAILABLE RADIONUCLIDE CONTROL TECHNOLOGY . . . . 3 


\section{LIST OF FIGURES}

1. The Hanford Site . . . . . . . . . . . . . . . 2

2. Location of the SSF within the 400 Area . . . . . . . . . . 3

3. SSF Piping Diagram .................. 6

4. Plan View of the Sodium Storage Facility .......... 9

\section{LIST OF TABLES}

1. SSF Radionuclide Inventory ................. 8

2. Aerosol Release Calculation Results ............ 13

3. Potential Annual Unabated Emissions from the SSF . . . . . . . . 14

4. Potential Annual Abated Emissions from the SSF .......... 14

5. Potential Annual Unabated Offsite Dose from the SSF . . . . . . . 15

6. Potential Annual Abated Offsite Dose from the SSF . . . . . . . 15 
DOE /RL-94-137, Rev. 0

TERMS

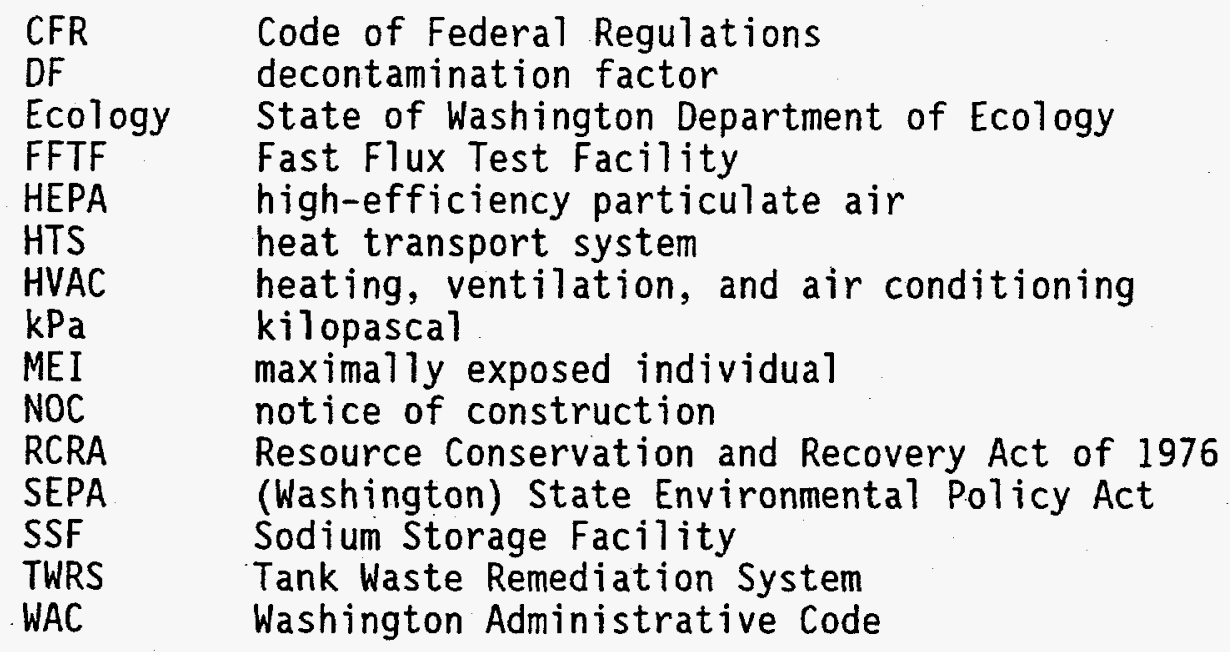

V 


\title{
RADIOACTIVE AIR EMISSIONS \\ NOTICE OF CONSTRUCTION \\ SODIUM STORAGE FACILITY
}

\subsection{INTRODUCTION}

The mission of the Sodium Storage Facility (SSF) is to receive molten sodium coolant from the Fast Flux Test Facility (FFTF), store the sodium in a solid state for an extended period, then melt the sodium for transfer to a future Sodium Reaction Facility. The SSF is a new facility required to support sodium offload during the transition of the FFTF to a safe and stable condition that is suitable for a long-term surveillance and maintenance phase pending final decommissioning. Because the majority of the FFTF systems must remain operational until the sodium is drained from the facility, availability of the SSF is crucial for achieving a timely and cost-effective transition of the FFTF.

Approximately 984,100 liters of sodium will be offloaded from the FFTF to tank storage in the SSF during this transition period. Unused, carbon steel sodium tanks originally built for the Clinch River Breeder Reactor Plant will be transported from their current location in the 300 Area and installed adjacent to the FFTF complex. Three 302,800-1iter tanks and one 196,800-1iter tank are available. Once the storage tanks are in place, a concrete building will be constructed around and over them to provide shielding and weather protection for the tanks and associated equipment. The sodium will be stored in a solid state, under an inert nitrogen gas blanket, until a sodium reaction facility is available to receive it (MAI, 1994).

This document serves as a notice of construction (NOC) pursuant to the requirements of Washington Administrative Code (WAC) 246-247-060 and as a request for approval to construct pursuant to 40 Code of Federal Regulations (CFR) 61.96 for the SSF.

The format of this document is different from that of previous NOC submittals. Information has been rearranged to more closely reflect the order of the requirements designated in WAC 246-247-110. Also, the requirements addressed by a particular section are called out in parentheses in the title of that section.

\subsection{FACILITY LOCATION (Requirement 1)}

The SSF will be located in the 400 Area of the Hanford Site, adjacent to the FFTF complex. Figure 1 shows the location of the 400 Area within the Hanford Site and Figure 2 shows the proposed location of the SSF within the 400 Area. The geodetic coordinates are:

\author{
Latitude: $46^{\circ} 26^{\prime} 5.74^{\prime \prime} \mathrm{N} \quad$ Longitude: $119^{\circ} 21^{\prime} 38.78^{\prime \prime} \mathrm{W}$ \\ U.S. Department of Energy, Richland Operations Office \\ Hanford Site \\ 400 Area, Fast Flux Test Facility \\ Richland, Washington 99352
}


Figure 1. The Hanford Site.

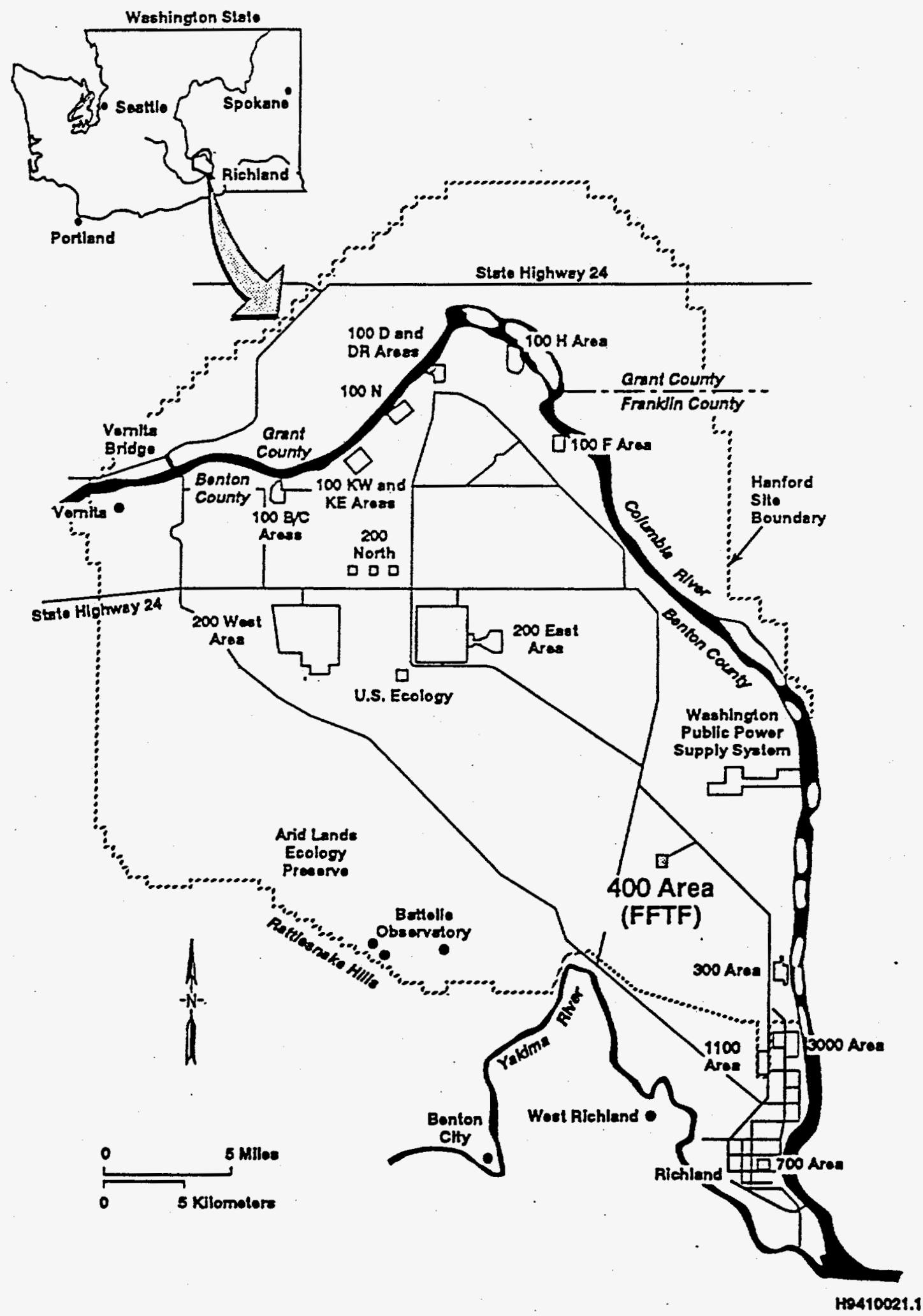




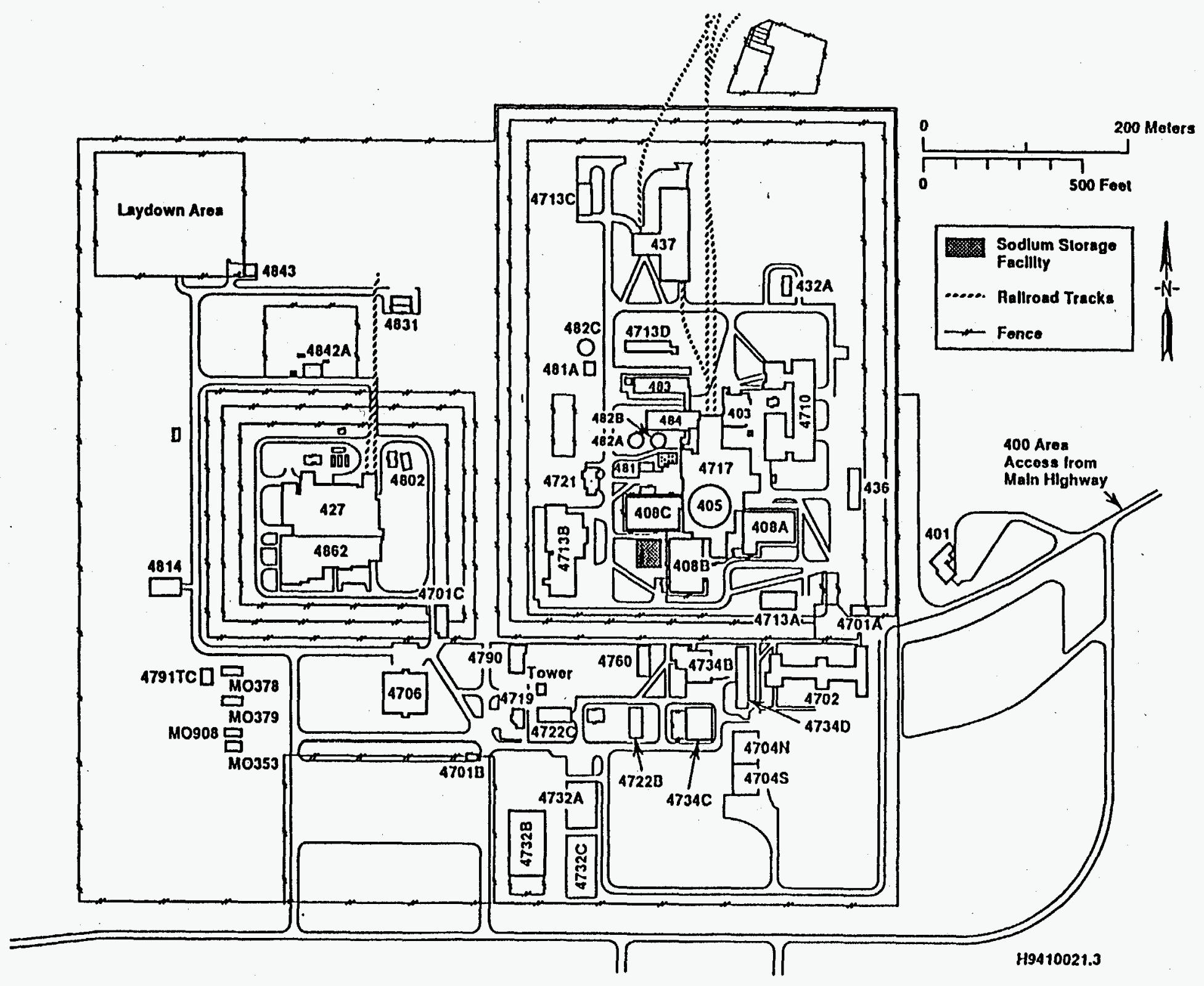




\subsection{RESPONSIBLE MANAGER (Requirement 2)}

The responsible manager's name and address are as follows:

Mr. J. E. Rasmussen, Acting Program Manager

Office of Environmental Assurance, Permits, and Policy

U.S. Department of Energy,

Richland Operations Office

P.0. Box 550

Richland, Washington 99352

(509) $376-2247$

\subsection{TYPE OF PROPOSED ACTION (Requirement 3)}

The SSF is a new emission unit.

\subsection{STATE ENVIRONMENTAL POLICY ACT (SEPA) (Requirement 4)}

A SEPA checklist was submitted to the State of Washington Department of Ecology (Ecology) on December 20, 1994. Mr. Geoff Tallent [(206) 407-7112] of Ecology coordinates all SEPA activities for the Hanford Site. The checklist will accompany the SSF Notice of Intent being submitted pursuant to the "Resource Conservation and Recovery Act (RCRA) of 1976," as amended.

\subsection{PROCESS DESCRIPTION (Requirements 5 and 7 )}

Sodium will be transferred to the SSF in batches from several different sodium storage/drain vessels within the FFTF. Following the transfer, the sodium will be allowed to solidify. Long-term storage of the sodium in a solid state within the SSF is expected to require minimal operations and maintenance support.

Sodium transfers will be accomplished in the following manner (MAI 1994). (Refer to Figure 3 for the piping diagram.)

1. The ventilation air flow rate in the storage tank area of the building will be established at a minimum of $43 \mathrm{~m}^{3} / \mathrm{min}$ by adjusting the motorized damper on the ventilation furnace inlets.

2. The receiving tank and interconnecting piping will be preheated to about $200{ }^{\circ} \mathrm{C}$ by electric heaters.

3. When the proper temperatures have been established, the sodium will be transferred from the supply tank to the receiving tank by a combination of pressure on the supply tank and a vacuum on the receiving tank. 
The supply tank will be pressurized to approximately 241 kilopascals $(\mathrm{kPa})$ using the existing FFTF argon piping. The receiving tank in the SSF will be evacuated to about $-69 \mathrm{kPa}$ using a vacuum pump and a high-efficiency particulate air (HEPA) filter connected to the tanks at the tank vent line.

4. The gas system valves will be closed and the sodium valves opened, allowing the sodium to flow from one tank to the other. The transfers will occur in batches, with more than one cycle needed to completely fill one SSF storage tank.

5. After all the transfers for a tank are complete, the inert gas system will be used to establish the desired cover gas pressure and the tank will be allowed to cool to ambient temperature, allowing the sodium sol idify.

6. When the sodium in all four storage tanks has solidified, the ventilation air flow rate will be reduced to a minimum of $11 \mathrm{~m}^{3} / \mathrm{min}$ and maintained there with the motorized damper controlled by building ambient temperature. 


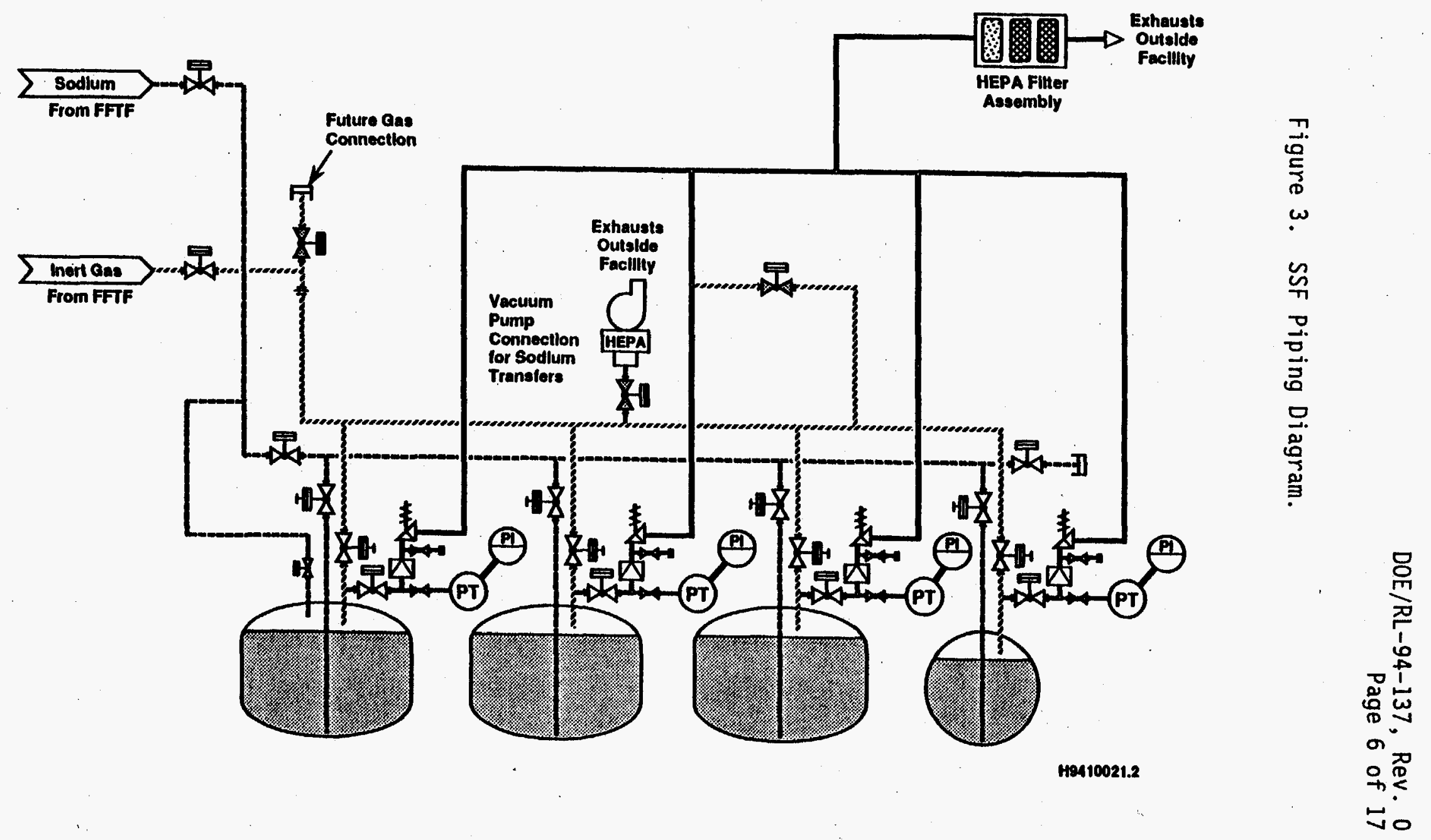




\subsection{ANNUAL POSSESSION QUANTITY AND PHYSICAL FORM}

(Requirements 8, 10, 11, and 12)

The bulk sodium coolant in the FFTF is contained within various systems throughout the plant: the Primary Heat Transport system (HTS), the Secondary HTS, Interim Decay Storage (IDS), and the Fuel Storage Facility (FSF).

The Primary HTS sodium (approximately 529,956 liters) contains radioactive sodium isotopes from neutron activation of the sodium during its passage through the reactor core. It also contains some fission and activation products that have leaked from the fuel and the absorber assemblies, as well as corrosion products.

The Secondary HTS sodium (approximately 249,836 liters) contains no activation products, but some tritium has diffused into the secondary system from the primary system through the intermediate heat exchanger. Secondary HTS tritium content is based on a measured concentration of tritium.

The IDS and FSF sodium (approximately 117,347 1iters and 87,064 1iters, respectively) have not been directly exposed to the reactor neutron flux, but do contain some radioactive elements originating from sodium transferred with fuel assemblies that were in the reactor or from the leakage of activation or fission products during storage of fuel and absorber assemblies. The radionuclide concentrations in the IDS and FSF sodium are much less than in the primary sodium.

Samples of Primary and Secondary HTS sodium have been analyzed to determine the quantity of radioactive elements contained in the sodium. Primary sodium radionuclide concentrations are conservatively assumed for all the sodium inventory except the Secondary HTS sodium. The most recent sodium samples/analyses were made in February 1993. The reactor has not operated since these samples were taken, so no additional radioactive isotopes have been produced. Table 1 shows the derived radionuclide inventory for the SSF based on the February 1993 isotopes and concentrations, then decayed four years in conjunction with the scheduled operation date of the SSF in April 1997 (Vankeuren 1994). These values are appropriate to represent the annual possession quantity for the entire year, because no new sources of inventory will be added or removed.

Table 1. SSF Radionuclide Inventory.

\begin{tabular}{|c|c|c|c|c|}
\hline \multicolumn{5}{|c|}{ Primary HTS, FSF, and IDS sodium $\left(734,367\right.$ liters $-6.7^{*} \times 10^{8}$ gms $)$} \\
\hline Isotope & $\begin{array}{l}\text { Physical } \\
\text { Form }\end{array}$ & $\begin{array}{c}\text { Specific } \\
\text { Activity on } \\
3 / 93 \text { (Ci/gm) }\end{array}$ & $\begin{array}{c}\text { Specific } \\
\text { Activity on } \\
3 / 97(\mathrm{Ci} / \mathrm{gm})\end{array}$ & $\begin{array}{c}\text { Total } \\
\text { Activity on } \\
3 / 97 \text { (Ci) }\end{array}$ \\
\hline $\begin{array}{c}\mathrm{Na}-22 \\
\mathrm{Cs}-137 \\
\mathrm{Pu}-239 \\
\mathrm{H}-3\end{array}$ & $\begin{array}{c}\text { Particulate } \\
\text { Particulate } \\
\text { Particulate } \\
\text { Gaseous }\end{array}$ & $\begin{array}{ll}5.2 & \mathrm{E}-07 \\
1.0 & \mathrm{E}-10 \\
1.2 & \mathrm{E}-12 \\
1.6 & \mathrm{E}-07 \\
\end{array}$ & $\begin{array}{ll}1.8 & E-07 \\
9.1 & E-11 \\
1.2 & E-12 \\
1.3 & E-07 \\
\end{array}$ & $\begin{array}{ll}1.2 & E+02 \\
6.1 & E-02 \\
8.0 & E-04 \\
8.5 & E+01\end{array}$ \\
\hline \multicolumn{5}{|c|}{ Secondary HTS sodium $\left(249,836\right.$ liters $\left.-2.3 \times 10^{8} \mathrm{gms}\right)$} \\
\hline $\mathrm{H}-3$ & Gaseous & 6.4 E-08 & $4.8 E-08$ & $1.1 E+01$ \\
\hline
\end{tabular}

FSF Fuel Storage Facility

HTS Heat Transfer System

IDS Interim Decay Storage 


\subsection{CONTROL SYSTEM (Requirement 6)}

\subsection{FACILITY OVERVIEW}

The SSF will consist of three 302,800-1iter tanks, one 196,800-1iter tank, and associated equipment. A concrete building will be constructed over and around the tanks to provide shielding and weather protection. The building will measure approximately $27 \mathrm{~m}$ by $28 \mathrm{~m}$ by $12 \mathrm{~m}$ high. Operating valves, sodium level probes, heating, ventilation, and air conditioning (HVAC) equipment, etc. will be located on a shielded mezzanine directly above the storage tanks. A plan of the facility is shown in Figure 4.

A secondary containment sump capable of containing the contents of one of the 302,800-1iter tanks will be provided. A metal floor with strategically located openings (holes/annulus) will cover the sump to 7 imit the oxygen available for combustion. Temporary level probes will be used in thimbles in each tank for monitoring during initial fill or any subsequent drain operation. Level monitoring will not be required once the sodium in the tanks solidifies. The storage tanks, piping, and heating equipment will be capable of heating and maintaining the equipment and sodium at a temperature between $177^{\circ} \mathrm{C}$ and $200{ }^{\circ} \mathrm{C}$. An inert cover gas blanket will be maintained over the sodium at all times. Each tank will be capable of withstanding either a full vacuum or an internal pressure of $345 \mathrm{kPa}$ at $200{ }^{\circ} \mathrm{C}$ (MAI 1994). 
Figure 4. Plan View of the Sodium Storage Facility.

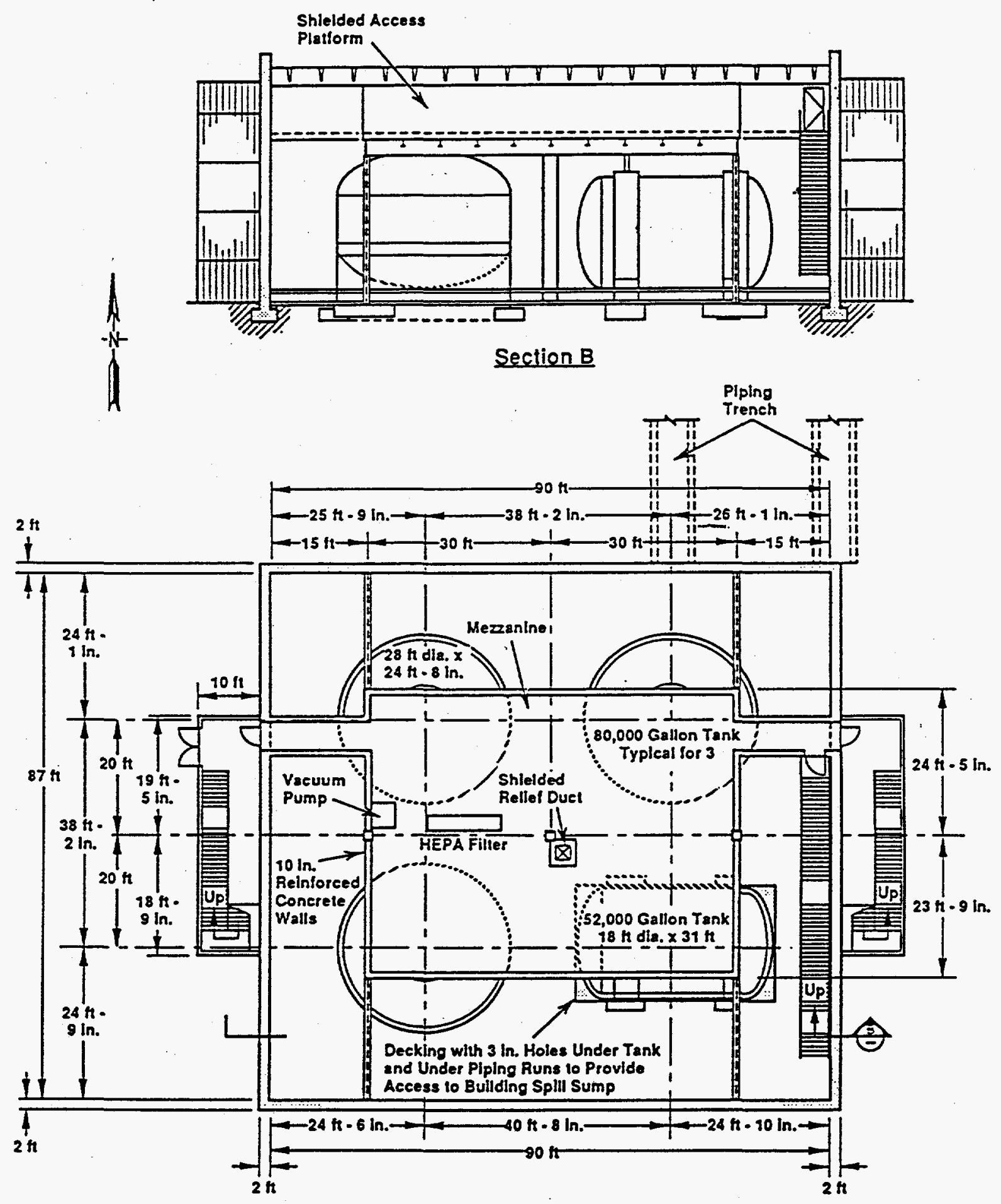

H9410021.4 


\subsection{BUILDING VENTILATION}

The building will use mechanical ventilation to keep temperatures below $49{ }^{\circ} \mathrm{C}$ in the summer and above $0{ }^{\circ} \mathrm{C}$ in the winter. To heat and maintain the storage tank area to the minimum required temperature, four $20-\mathrm{kW}, 57-\mathrm{m}^{3} / \mathrm{min}$ up-flow furnaces with two $36-\mathrm{cm}$ ducts will be used. Ventilation air is supplied from the outside. During sodium transfer operations and while the sodium remains molten, the ventilation air flow rate will be at least $43 \mathrm{~m}^{3} / \mathrm{min}$. After the sodium in all four tanks has solidified, the building will be in the sodium storage mode and the ventilation air flow rate will be kept at $11 \mathrm{~m}^{3} / \mathrm{min}$ or greater. Because design standards and codes, operational controls and procedures preclude the area from containing airborne radioactive material, ventilation air is exhausted to the outside through the roof (MAI, 1994).

\subsection{STORAGE TANK COVER GAS SYSTEM}

The cover gas from inside the tanks can be exhausted from the facility from three places: the vacuum pump exhaust, the storage tank vent lines, or the storage tank pressure relief lines. (Refer to Figure 4.)

The vacuum pump, used only during sodium transfers, will be connected to the storage tank vent and pressure relief system using a quick disconnect fitting. HEPA filtration will be provided on the inlet to the vacuum pump with the discharge being vented to the outside.

A separate HEPA filter assembly will be provided for the tank vent and pressure relief systems. The filter assembly will be sized to provide a drop of less than the design pressure across the filter at the highest flow rate encountered (either venting or during actuation of the safety relief valve). The HEPA filter assembly will consist of a prefilter and two stages of HEPA (99.95-percent efficient) filtration. Its discharge will be routed directly through the roof of the SSF.

Over-pressure protection will be provided for each tank. The protection will consist of a rupture disk and a pressure relief valve installed in series. This combination prevents air exposure to the inside of the tank after a release or during maintenance or testing of the relief valve. The values will exhaust $1 \mathrm{~m}^{3} / \mathrm{min}$ at $345 \mathrm{kPa}$. Gases vented from the pressure relief valves will be routed to a $15-\mathrm{cm}-$ diameter header that discharges through the HEPA filter assembly (MAI, 1994).

\subsection{MONITORING SYSTEM (Requirement 9)}

In accordance with 40 CFR 61 Subpart $H$, periodic confirmatory measurements will be performed. 


\subsection{RELEASE RATES (Requirement 13)}

This section contains information and calculations regarding unabated release rates and abated release rates from the SSF. Two scenarios are assessed for releases without an emission control system in place: emissions during sodium transfer operations and emissions in the sodium storage mode. The unabated emissions are summarized in Table 3 and the abated emissions are summarized in Table 4.

\subsection{UNABATED EMISSIONS DURING SODIUM TRANSFER OPERATIONS}

Two types of releases are considered possible during the sodium transfer operations (Prevo, 1994):

- A tritium release caused by venting of the cover gas over previously transferred sodium that is contaminated with tritium

- A radioactive sodium aerosol release caused by the elevated temperatures during the transfer.

Both are discussed in the following sections.

\subsubsection{Tritium Release}

The method proposed for transferring the sodium from the FFTF to the SSF involves preheating and placing a vacuum on a storage tank in the SSF, opening the correct valves to connect the storage tank with the appropriate FFTF sodium system, and finally transferring liquid sodium. Pressure will be applied to the argon cover gas over the FFTF sodium to transfer the sodium. The SSF storage tanks will not be contaminated before receiving the first transfer of sodium. If the SSF storage tanks can be filled in one batch, essentially no tritium will be released. However, several batch transfers will be needed to fill each tank, which may require evacuating the argon cover gas before each transfer. Therefore, on subsequent evacuations, the argon gas may be contaminated with tritium.

The following is a conservative analysis to determine the maximum amount of tritium that could be released during the transfer of all the sodium to the SSF.

\section{Assumptions:}

- The equivalent of one tank volume at standard temperature and pressure is evacuated after the initial contamination-free pump down

- The initial evacuation may provide a sufficient pressure drop to complete the sodium transfer; however, assuming an additional tank volume is considered a conservative approach, because subsequent evacuations would be made at a reduced pressure 
- The concentration of tritium in the primary sodium, conservatively assumed to fill three of the 302,800-1iter tanks, is the same as historical concentrations of tritium in the reactor cover gas (about $\left.5 \times 10^{-5} \mu \mathrm{Ci} / \mathrm{ml}\right)$

- The concentration of tritium in the secondary sodium (assumed to fill the 196,800-liter tank) is equal to the historical concentration of the secondary sodium cover gas (about $4 \times 10^{-6} \mu \mathrm{Ci} / \mathrm{ml}$ ). The remaining 52,996 liters of secondary sodium will go to a $302,800-1$ iter tank.

The amount of tritium released during the fill of one tank with primary sodium would be:

$$
(302,800 \text { 1iters })\left(10^{3} \mathrm{ml} / 1 \text { iter }\right)\left(5 \times 10^{-5} \mu \mathrm{Ci} / \mathrm{ml}\right)=1.5 \times 10^{4} \mu \mathrm{Ci}
$$

For three tanks, the amount of tritium would be:

$4.5 \times 10^{4} \mu \mathrm{Ci}$ or $4.5 \times 10^{-2} \mathrm{Ci}$

The amount released during the fill of the 196,800-1iter tank with secondary sodium would be:

$$
\begin{aligned}
& (196,8007 \text { iters })\left(10^{3} \mathrm{~m} 7 / 1 \text { iter }\right)\left(4 \times 10^{-6} \mu \mathrm{Ci} / \mathrm{ml}\right)=7.9 \times 10^{2} \mu \mathrm{Ci} \\
& \text { or } 7.9 \times 10^{-4} \mathrm{Ci}
\end{aligned}
$$
be:

The total amount of tritium released from filling all four tanks would

$$
\left(4.5 \times 10^{-2}\right)+\left(7.9 \times 10^{-4}\right)=4.6 \times 10^{-2} \mathrm{Ci} .
$$

\subsubsection{Aerosol Release}

Any radioactivity released as aerosols would be very small, because the vapor pressure for sodium at $200^{\circ} \mathrm{C}$ is very $10 \mathrm{w}\left(2 \times 10^{-7}\right.$ atmospheres $)$. The following assumptions are conservative and the actual releases are expected to be less than the calculated values. Calculations to determine the airborne concentrations are presented below.

Assumptions:

- Before filling a 302,800-liter tank with sodium, the tank has been evacuated and backfilled with cover gas $\left(3.03 \times 10^{8} \mathrm{ml}\right)$

$$
(302,800 \text { liters })\left(10^{3} \mathrm{ml} / 1 \text { iter }\right)=3.03 \times 10^{8} \mathrm{ml}
$$

- At the start of the filling process, radionuclides are entrained in the cover gas at the maximum values as derived in the following steps

- During the filling process, the entire $3.03 \times 10^{8} \mathrm{ml}$ of cover gas is released 
Once again, the initial evacuation may provide a sufficient pressure drop to complete the sodium transfer; however, assuming an entire tank volume is considered a conservative approach because subsequent evacuations would be made at a reduced pressure

- At ideal gas conditions of 1 atmosphere vapor pressure, $0{ }^{\circ} \mathrm{C}$ temperature and 22 liters of air, and applying the Ideal Gas Law, the 22 liters of air would contain $23 \mathrm{~g}$ of sodium

The amount of sodium in $22 \mathrm{~L}$ of air at $2 \times 10^{-7}$ atmospheres can be determined by using ratios of grams of sodium to atmospheres:

\section{$\frac{23 \text { grams }}{1 \mathrm{~atm}} \quad \frac{\times \text { grams }}{2 \times 10^{-7} \mathrm{~atm}}$}

Therefore, $22 L$ of air contain $4.6 \times 10^{-6} \mathrm{gm}$ of sodium. Converting to $\mathrm{gm} / \mathrm{ml}$ gives $2.1 \times 10^{-10} \mathrm{gm}$ of sodium per $\mathrm{ml}$.

To obtain concentrations of individual radionuclides, their specific activities in the sodium are multiplied by the $2.1 \times 10^{-10} \mathrm{gm} / \mathrm{ml}$ sodium aerosol concentration. Results are shown in Table 2. To obtain individual radionuclide activities, their concentration values, calculated above, are multiplied by the entire volume of the cover gas $\left(3.03 \times 10^{8} \mathrm{ml}\right)$. These results are also shown in Table 2 .

Table 2. Aerosol Release Calculation Results.

\begin{tabular}{||c|c|c|c|c|}
\hline Radionuclide & $\begin{array}{c}\text { Specific } \\
\text { activity on } \\
3 / 97 \\
(\mathrm{Ci} / \mathrm{gm})\end{array}$ & $\begin{array}{c}\text { Airborne } \\
\text { sodium } \\
\text { concentration } \\
\text { (gm/ml) }\end{array}$ & $\begin{array}{c}\text { Airborne } \\
\text { radionuclide } \\
\text { concentration } \\
\text { (Ci /ml) }\end{array}$ & $\begin{array}{c}\text { Airborne } \\
\text { radionuclide } \\
\text { activity } \\
\text { (Ci) }\end{array}$ \\
\hline${ }^{22} \mathrm{Na}$ & $1.8 \mathrm{E}-07$ & $2.1 \mathrm{E}-10$ & $3.8 \mathrm{E}-17$ & $1.2 \mathrm{E}-08$ \\
\hline${ }^{137} \mathrm{Cs}$ & $9.1 \mathrm{E}-11$ & $2.1 \mathrm{E}-10$ & $1.9 \mathrm{E}-20$ & $5.8 \mathrm{E}-12$ \\
\hline${ }^{239} \mathrm{Pu}$ & $1.2 \mathrm{E}-12$ & $2.1 \mathrm{E}-10$ & $2.5 \mathrm{E}-22$ & $7.6 \mathrm{E}-14$ \\
\hline
\end{tabular}

\subsection{UNABATED EMISSIONS DURING SODIUM STORAGE}

The sodium will be stored in the SSF in a solid form after cooling. The cooling could take several months, because of the insulation of the tanks and the high heat capacity of large quantities of sodium. The temperature of the sodium and the tanks during transfers and cooldown to ambient will be $200{ }^{\circ} \mathrm{C}$ or less. The diffusion of tritium through metal is lower at lower temperatures. The pressure relief system will relieve $68 \mathrm{~m}^{3} / \mathrm{min}$ at $345 \mathrm{kPa}$. The cover gas pressure on each tank will be controlled manually with the cover gas space normally being stagnant.

Considering the low sodium temperatures, solid sodium, and stagnant cover gas, possible releases of tritium during sodium storage would be significantly less than those during sodium transfer operations (Prevo, 1994). 


\subsection{SUMMARY OF UNABATED EMISSIONS}

Table 3 lists the potential annual unabated emissions from the SSF representing combined quantities from the previously discussed scenarios.

Table 3. Potential Annual Unabated Emissions from the SSF.

\begin{tabular}{|c|c|}
\hline Radionuclide & Emission $(\mathrm{Ci} / \mathrm{yr})$ \\
\hline \hline${ }^{3} \mathrm{H}$ & $4.6 \mathrm{E}-02$ \\
\hline${ }^{22} \mathrm{Na}$ & $1.2 \mathrm{E}-08$ \\
\hline${ }^{137} \mathrm{Cs}$ & $5.8 \mathrm{E}-12$ \\
\hline${ }^{239} \mathrm{Pu}$ & $7.6 \mathrm{E}-14$ \\
\hline
\end{tabular}

\subsection{ABATED EMISSIONS}

Abated emissions are conservatively calculated using the decontamination factor ( $D F=1 / 1$-efficiency) for one HEPA filter only and not taking into account the prefilter and second-stage HEPA filter, which are also part of the filter assembly. Abated emissions are calculated by dividing the DF into the unabated emissions. Results are shown in Table 4.

Table 4. Potential Annual Abated Emissions from the SSF.

\begin{tabular}{|c|c|c|c|}
\hline Radionuclide & $\begin{array}{c}\text { Unabated emission } \\
(\mathrm{C} i / \mathrm{yr})\end{array}$ & $\begin{array}{c}\text { Decontamination } \\
\text { factor }\end{array}$ & $\begin{array}{c}\text { Abated emission } \\
(\mathrm{C} \mathrm{j} / \mathrm{yr})\end{array}$ \\
\hline \hline${ }^{3} \mathrm{H}$ & $4.6 \mathrm{E}-02$ & 1 & $4.6 \mathrm{E}-02$ \\
\hline${ }^{22} \mathrm{Na}$ & $1.2 \mathrm{E}-08$ & $2.0 \mathrm{E}+03$ & $6.0 \mathrm{E}-12$ \\
\hline${ }^{137} \mathrm{Cs}$ & $5.8 \mathrm{E}-12$ & $2.0 \mathrm{E}+03$ & $2.9 \mathrm{E}-15$ \\
\hline${ }^{239} \mathrm{Pu}$ & $7.6 \mathrm{E}-14$ & $2.0 \mathrm{E}+03$ & $3.8 \mathrm{E}-17$ \\
\hline
\end{tabular}

To address any opacity concerns, the potential total particulate concentration at the stack exit was calculated by dividing the DF into $2.1 \mathrm{E}-10 \mathrm{gm}$ of sodium per $\mathrm{ml}$ of air, derived in Section 10.1.2, and converting the units into $\mu \mathrm{gm} / \mathrm{m}^{3}$.

The potential total particulate concentration at the stack exit would be: $\left[\left(2.1 \times 10^{-10} \mathrm{gm} / \mathrm{m}^{3}\right) / 2 \times 10^{3}\right]\left(10^{6} \mathrm{ml} / \mathrm{m}^{3}\right)\left(10^{-6} \mu \mathrm{gm} / \mathrm{gm}\right)=$
$1.05 \times 10^{-13} \mu \mathrm{gm} / \mathrm{m}^{3}$ 


\subsection{OFFSITE IMPACT (Requirements 14 and 15)}

This section contains information regarding the effective dose equivalents to the maximally exposed individual (MEI) off site resulting from unabated and abated emissions from the SSF. The MEI is located 8,100 meters south of the 400 Area. The potential unabated doses are summarized in Table 5 and the potential abated doses are summarized in Table 6 . The unit dose factors included in the tables were previously submitted to the State of Washington Department of Health. The information required to develop the unit dose factors from the Clean Air Assessment Package 1988 computer code was also included in "Unit Dose Calculation Methods Summary of Facility Effluent Monitoring Plan Determinations" (WHC 1991).

Table 5. Potential Annual Unabated Offsite Dose from the SSF.

\begin{tabular}{|c|c|c|c|}
\hline Radionuclide & $\begin{array}{c}\text { Unit dose factor } \\
\text { (mrem/Ci) }\end{array}$ & $\begin{array}{c}\text { Unabated emission } \\
(\mathrm{Ci} / \mathrm{yr})\end{array}$ & $\begin{array}{c}\text { Unabated dose } \\
\text { (mrem/yr) }\end{array}$ \\
\hline${ }^{3} \mathrm{H}$ & $2.83 \mathrm{E}-05$ & $4.6 \mathrm{E}-02$ & $1.3 \mathrm{E}-06$ \\
\hline${ }^{22} \mathrm{Na}$ & $2.56 \mathrm{E}-02$ & $1.2 \mathrm{E}-08$ & $3.1 \mathrm{E}-10$ \\
\hline${ }^{137} \mathrm{Cs}$ & $3.17 \mathrm{E}-02$ & $5.8 \mathrm{E}-12$ & $1.8 \mathrm{E}-13$ \\
\hline${ }^{239} \mathrm{Pu}$ & $1.15 \mathrm{E}+01$ & $7.6 \mathrm{E}-14$ & $8.7 \mathrm{E}-13$ \\
\hline Total & $\mathrm{N} / \mathrm{A}$ & $\mathrm{N} / \mathrm{A}$ & $1.3 \mathrm{E}-06$ \\
\hline
\end{tabular}

Table 6. Potential Annual Abated Offsite Dose from the SSF.

\begin{tabular}{|c|c|c|c|}
\hline Radionuclide & $\begin{array}{c}\text { Unit dose factor } \\
\text { (mrem/Ci) }\end{array}$ & $\begin{array}{c}\text { Abated emission } \\
\text { (Ci/yr) }\end{array}$ & $\begin{array}{c}\text { Abated dose } \\
\text { (mrem/yr) }\end{array}$ \\
\hline${ }^{3} \mathrm{H}$ & $2.83 \mathrm{E}-05$ & $4.6 \mathrm{E}-02$ & $1.3 \mathrm{E}-06$ \\
\hline${ }^{22} \mathrm{Na}$ & $2.56 \mathrm{E}-02$ & $6.0 \mathrm{E}-12$ & $1.5 \mathrm{E}-13$ \\
\hline${ }^{137} \mathrm{Cs}$ & $3.17 \mathrm{E}-02$ & $2.9 \mathrm{E}-15$ & $9.2 \mathrm{E}-17$ \\
\hline${ }^{239} \mathrm{Pu}$ & $1.15 \mathrm{E}+01$ & $3.8 \mathrm{E}-17$ & $4.4 \mathrm{E}-16$ \\
\hline Total & $\mathrm{N} / \mathrm{A}$ & $\mathrm{N} / \mathrm{A}$ & $1.3 \mathrm{E}-06$ \\
\hline
\end{tabular}

The 1993 calendar year emissions for the 400 Area would result in a dose of $8.7 \mathrm{E}-05 \mathrm{mrem} / \mathrm{yr}$ to the same MEI located $8,100 \mathrm{~m}$ south of the 400 Area (RL 1994). The estimated dose of $1.3 \mathrm{E}-06 \mathrm{mrem} / \mathrm{yr}$ from the SSF is nearly two orders of magnitude below the 400 Area dose for 1993. The dose resulting from a11 Hanford Site operations in 1993, was determined to be $6.3 \mathrm{E}-03 \mathrm{mrem} / \mathrm{yr}$ for an individual located at the Sagemore Road farm, excluding radon (RL 1994). The emissions originating from the SSF, in conjunction with other current operations at the Hanford Site, will not result in a violation of the National Emission Standard of ten mrem/yr. The potential increase of emissions from the SSF is negligible. 


\subsection{FACILITY LIFETIME (Requirement 17)}

The SSF will provide safe, environmentally sound storage for approximately 984,100 liters of elemental sodium presently in the FFTF cooling system. The SSF will have a design 1 ife of 40 years for the roof and 20 years for the structure and contents.

Sodium transfers will extend over approximately 18 months. Following the transfer, the sodium will be allowed to solidify. Long-term storage of the sodium in a solid state within the SSF will require minimal operations and maintenance support. Subsequent transfer from the SSF to a future reaction facility is expected to take approximately two years.

A new use for the sodium, converted to sodium hydroxide, has been identified by the Tank Waste Remediation System (TWRS) Program for caustic washing as part of the high-level waste tank sludge pretreatment process. The FFTF Transition Project and the TWRS Program technical baselines include planning for storage of the sodium pending use of this material for the TWRS pretreatment process in approximately 2008. If the baseline changes, the sodium would be converted to a stable solid form suitable for land disposal (i.e., sodium sulfate or sodium tetraborate).

\subsection{TECHNOLOGY STANDARDS (Requirement 18)}

Applicable sections or requirements of the control technology standards, 1 isted under requirement 18, will be reviewed and incorporated into the design during the definitive design process of the SSF.

HEPA filters will be installed on air pathways to control particulate emissions resulting from the venting of cover gases from the storage tanks during sodium transfers or the venting from potential over pressurization of the storage tanks. 


\subsection{REFERENCES}

40 CFR 60, "Standards of Performance for New Stationary Sources," Code of Federal Regulations, as amended.

40 CFR 61, "National Emission Standards for Hazardous Air Pollutants, " Code of Federal Regulations, as amended.

Beres, D. A., 1990, Clean Air Assessment Package - 1988 (CAP-88). "A Dose and Risk Assessment Methodology for Radionuclide Emissions to Air," Vols. 1-3, U.S. Environmental Protection Agency, Washington, D.C.

MAI, 1994, Conceptual Design Report Project F-031, "Sodium Storage Facility, $60 \%$ Complete, "Meier Associated, Inc. P.S., Kennewick, Washington.

Polzin, D. L., 1994, Functional Design Criteria, "Sodium Storage Facility," WHC-SD-FF-FDC-009, Rev. 0, Westinghouse Hanford Company, Richland, Washington.

Prevo, P. R., 1994, "Potential Release of Radioactivity from the Sodium Storage Facility," Internal Memo to D. L. Nielsen, October 4, Westinghouse Hanford Company, Richland, Washington.

RL, 1994, "Radionuclide Air Emissions Report for the Hanford Site, Calendar Year 1993," June 1994, DOE/RL-94-51, U.S. Department of Energy, Rich1 and Operations Office, Richland, Washington.

Vankeuren, J. C., August 8, 1994, "Hazard Categorization and Classification for the Sodium Storage Facility," WHC-SD-FF-HC-002, Rev. 0, Westinghouse Hanford Company, Richland, Washington.

WAC 246-247, "Radiation Protection - Air Emissions," Washington Administrative Code, as amended.

WHC, 1991, "Unit Dose Calculation Methods Summary of Facility Effluent Monitoring Plan Determinations, "WHC-EP-0498, Westinghouse Hanford Company, Richland, Washington. 
DOE/RL-94-137, Rev. 0

APPENDIX A

DISCUSSION OF BEST AVAILABLE RADIONUCLIDE CONTROL TECHNOLOGY 

DOE/RL-94-137, Rev. 0

\section{APPENDIX A}

\section{DISCUSSION OF BEST AVAILABLE RADIONUCLIDE CONTROL TECHNOLOGY}

Best Available Radionuclide Control Technology (BARCT) is defined by Washington Administrative Code (WAC) 246-247-030 as follows:

"Technology that will result in a radionuclide emission limitation based on the maximum degree of reduction for radionuclides from any proposed newly constructed or significantly modified emission units that the licensing authority determines is achievable on a case-bycase basis. A BARCT compliance demonstration must consider energy, environmental, and economic impacts, and other costs through examination of production processes, and available methods, systems, and techniques for the control of radionuclide emissions. A BARCT compliance demonstration is the conclusion of an valuative process that results in the selection of the most effective control technology from all known feasible alternatives. In no event shall application of BARCT result in emissions of radionuclides that could exceed the applicable standards of WAC 246-247-040. Control technology that meets BARCT requirements also meets ALARACT requirements."

As stated in WAC 246-247-120, only those radionuclides comprising more than ten percent of the unabated dose need to be evaluated. Well over 99.9 percent of the unabated dose is caused by emissions of tritium. No controls are currently available for the control of tritium from stationary sources, except that condensation can be used if the tritium is in the form of tritiated water. The tritium emissions from the SSF are in the form of HT, therefore condensation (which rarely passes the impact analyses of the BARCT assessment) is not an effective control technology. Consequently, no controls for tritium are proposed as BARCT. 